\title{
THE PLAYING GROUNDS OF CHILDHOOD: BOYHOOD BATTLES IN AMÉRICO PAREDES' GEORGE WASHINGTON GÓMEZ
}

\section{Delores Ayers Keller Rice University}

Although playing is generally viewed as a childhood universal-an expected and somewhat innocuous part of children's lives-Chicano writers often particularize play's universality by constructing the diverse grounds of childhood play as sites that encapsulate conflicting subject positions. Among the Chicano texts in which playing shares this complexity as a critical locus for the child protagonist is Américo Paredes' George Washington Gómez. Paredes employs narratives of childhood play in a dialectical pattern that elucidates his protagonist's inner and outer conflicts and that also evokes Ramón Saldívar's theory of Chicano literature. While Guálinto Gomez's playworlds reflect both the violence and discrimination that surround him in the real world and highlight his struggles with his dual American and Mexican identity, Paredes provides no synthesis for his protagonist's dialectical dilemma of 
doubleness.

In Chicano literature children and childhood have been prominent concerns, and, according to Chicano literary critic and theorist, Juan Bruce-Novoa, "By the early 1970s, the [Chicano] novel tended to fall loosely within one pattern, that of the Bildungsroman" (82). As Ted Lyon also notes, "Much of contemporary Chicano prose creates a child or adolescent protagonist, narrator, or focus character" engaged in a "search for identity" that entails "the concept of 'loss of innocence" (255). In this "search for identity" many of the children in Chicano literature find themselves situated precariously at the crossroads of two cultures, languages, and loyalties and confronted with dilemmas and oppositions that seem impossible to reconcile. While Chicano children have a "wide diversity" of life experiences during childhood, Chicano writers often incorporate an overriding theme into that diversity-"the troubled adjustment of Mexican Americans to American culture" (Portales 69, 48). In the articulation of this "troubled" position, Chicano authors frequently employ the motif of childhood play as a site of both destructive and constructive experience for their child characters.

Although playing is generally viewed as a childhood universal-an expected and somewhat innocuous part of children's lives-Chicano writers particularize play's universality by constructing the diverse grounds of childhood play as sites that encapsulate conflicting subject positions. According to Rosaura Sánchez, it is the "general marginalization in society, on the basis of class, ethnicity, and gender, that Chicano literature has reconstructed textually" (1011), and the children in Chicano literature are often acutely aware of their marginalized status both as children subject to adult authority and as Chicanos subject to societal oppression. Sánchez also asserts that

Chicano novelists and short story writers have used many literary strategies to call attention to the cultural, political, and economic constraints within which Chicanos live and work, constraints formative of discourses used to construct Chicano subjectivities" (1021). 


\section{Ethnic Studies Review Volume 25}

For Chicano writers one of these "literary strategies" is the use of narratives of playing in which the site of play embodies the internal and external oppositions that plague children as they move from childhood to adolescence and into adulthood. In these fictional worlds of play, issues of race, ethnicity, class, and gender often collide with the processes of identity formation and the loss of naiveté, and as a result the site of play becomes a complex ground of multiple struggles with self-definition. Among the Chicano texts in which playing shares this complexity as a critical locus for the child protagonist is Américo Paredes' George Washington Comez.1 By alternating between situations that conflate play experiences with real world experiences and situations that place the two in opposition, Paredes elucidates his protagonist's inward and outward struggles to define himself and to cope with the often violent erasure of "the disjunction of childhood innocence and adult maturity" (Sutton-Smith 115116).

According to play theorist Brian Sutton-Smith, one of the popularly held ideologies about childhood play is the belief that play is "frivolous" $(10,11)$. However, the "rhetoric" which relegates play to the realm of frivolity "takes on a much more serious purpose when we view it as an implicit form of political or scholarly denigration" (207-208). Sutton-Smith argues that this "denigration of play in intellectual terms is shown by the absence of the key term play from the index of almost every book about the behavior of human beings". (208)

Furthermore, Sutton-Smith asserts that whenever "the spontaneous play of children, women, [and] minority groups" is classified "as trivial or frivolous," this categorization serves to demean "these [already] denigrated groups." Moreover, "[a]Il of these denigrated groups are generally as deadly serious . . . about their own play as are those who denigrate them; they are not frivolous in their own eyes; they are seriously at play". (208).

Significantly in their serious play pursuits children often disassemble "the world . . . in a way that suits their own emotional responses to it," and in this way "their play is a deconstruction of the world in which they live" $(208,166)$. Yet at the same time the player must retain "supreme awareness of the two levels of being, the virtual and the mundane, and how she [or he] can 
interact with both of them." The "manipulation of that duality is central to the character of . . p play. There is the mundane and there is the virtual (as thesis and antithesis) and there is a synthesis in the ongoing play transformations that this duality then produces, and so, structurally, it is a dialectic" (196).

Recognizing both the pivotal role of play in human behavior and its dialectical nature, Paredes constructs the site of playing as much more than a space of frivolity. In George Washington Gomez Parades employs narratives of boyhood play in order to foreground the dialectical nature of his protagonist's inner and outer conflicts in a strategy that evokes Ramón Saldívar's theory of Chicano literature. According to Saldívar, instead of "passively reproducing images of reality, the task of contemporary Chicano narrative is to deflect, deform, and thus transform reality by revealing the dialectical structures that form the base of human experience."

Saldivar suggests,

In opting for open over closed forms, for conflict over resolution and synthesis, in proclaiming its very difference, the function of Chicano narrative is thus to produce creative structures of knowledge to allow its readers to see, to feel, and to understand their social reality. Saldivar further explains this process as one of "duality," and asserts, "The ideology of difference of Chicano narratives emerges from ... its paradoxical impulse toward revolutionary deconstruction and toward the production of meaning" (CN 7). He states that Chicano texts

must be understood as different from and in resistance to traditional American literature, yet must also be understood in their American context, for they take their oppositional stance deliberately in order to offer readers a reformulation of historical reality and contemporary culture that is more consistent with the way reality and culture are actually experienced ( $\mathrm{CN} 8-9)$.

George Washington Gomez, published in 1990 but written by Paredes in the late 1930s, ${ }^{2}$ possesses both "a reformulation of historical reality" (CN 9) through correctives to the historical account as rendered by the colonizer ${ }^{3}$ and contemporary relevance, for, as Marco Portales asserts, 


\section{Ethnic Studies Review Volume 25}

The educational practices and attitudes revealingly dramatized by Paredes in the 1920s and 1930s still largely shape the educations that Chicanos and other Latinos and minority students experience in the United States (83).

Portales notes that Paredes' child protagonist is trapped "in an education system that does not even try to understand the values and ways of Mexican American culture" (85). As Portales points out, "Paredes . . . makes it clear that formidable social pressures everywhere force Chicanos to choose between being Mexican or American"; thus Paredes effectively "captures the quandary of Mexican American split-allegiance" (94).

According to Saldivar, "Américo Paredes has argued that this sense of 'an in-between existence' characterizes Mexican American border culture" and "also characterizes one aspect of the complex polarity of identity, both Mexican and American but neither one nor the other fully, that is so evident in contemporary Chicano narrative". (CN 17-18).

The "sense of "an in-between existence"" is powerfully depicted in Paredes' George Washington Gomez, which "takes especially as its moment the 1915 uprising in South Texas by Mexican Americans attempting to create a Spanish-speaking republic of the Southwest (Saldivar, "Borderlands." 276). The "seditionists" of this uprising were "answering deep-seated feelings of anger and frustration over Anglo oppression and injustice," but "were overwhelmed by the American military forces." During "the aftermath of the seditionist uprising, hundreds of innocent Mexican-American farmers and ranchers were slaughtered by Texas Rangers, summarily executed without trial at even the smallest hint of possible alliance with, or even sympathy for, the seditionists". (276). As Saldivar explains, "Paredes' novel situates us in the midst of this historical scenario, taking its tone from the pathos of those innocents from whom was exacted the cost of defeat" (277). However, as Monika Kaup states, "While the hero of the seditionist prologue to the novel is Feliciano, the courageous defender of the old order, [Paredes places] the focus of the main plot ... on the next generation, and its subject is the formation of a new dual and conflicted, Mexican and American identity". (373). 
The representative of this "next generation" in Paredes' George Washington Comez is the child protagonist who bears the same name as the title of the novel. Born in 1914 and called Guálinto by his friends and family, he and his older sisters, Carmen and Maruca, are raised by their mother, María, and her brother, Feliciano, after the murder of their father. Set primarily in the fictional border town of Jonesville, this narrative, which begins in the early years of the 20th century and concludes during the years of World War II, is the story of Guálinto's struggle to come to terms with his identity as both a Mexican and an American. One of the crucial considerations in this text is that Guálinto does not know the truth about his father's death nor does he know that his Uncle Feliciano was a part of the band of men who wanted to reclaim the lands that the gringos had stolen from the Mexican people of south Texas. Although Guálinto's father, Gumersindo, is murdered by Texas Rangers shortly after Guálinto's birth, Gumersindo is able to make a dying wish known to Guálinto's Uncle Feliciano: “Gumersindo opened his eyes and looked at Feliciano with no hint of surprise. 'Don't tell him,' he mumbled through bruised lips. . . . 'My son mustn't know. Ever. No hate, no hate'". (GWG 21) Feliciano, although appalled by this request, promises to abide by Gumersindo's wishes.

Settling in Jonesville after Gumersindo's murder, Feliciano obtains work and provides María and her family with a home that "[i]n later years George W. Gómez would remember . . . as an enchanted place" (50). ${ }^{4}$ Feliciano has regrets about his promise to Gumersindo but remembers that "[m]any times before, Gumersindo had said that he wanted his son to have no hatred in his heart"; Guálinto "must grow up to be a great man and help his people." Feliciano, nevertheless, reflects on the difficulty of keeping this promise: "It would be very hard to keep such a terrible truth from this male child. Never to tell him how his father died, never to give him a chance at vengeance" (31). Yet while Feliciano keeps his promise for many years, he is unable to shelter the child Guálinto from other forms of knowledge and real world experiences that are just as capable of producing hatred and anger.

During the early years of his childhood, however, Guálinto 


\section{Ethnic Studies Review Volume 25}

does have a tangible shelter from the outside world in the form of the banana tree grove behind his home that his Uncle Feliciano had planted when Guálinto was an infant. Guálinto is enthralled with this grove that is his backyard retreat and playing ground of magical make-believe: "Here Guálinto hunted tigers and engaged pirates. Here he became a lone Indian tracking the wounded deer." However, the banana grove possesses a dual nature for Guálinto who fears the night: "With darkness the banana grove and the trees beyond it became a haunted wood where lurked demons, skeletons and white-robed women with long long hair". Guálinto's imaginary fears parallel real world events, for his "neighborhood, being at the edge of town, had seen more than its share of [political] bloodshed"; thus the bodies of the victims "haunted the night" for Guálinto, whose "mother tried to calm his fears with religion" (50). Before going to bed each night, he says a prayer which ends with the lines, "If I die without the grace of God/l shall burn in Hell forever," and these words cause him to lie in bed "hat[ing] God for being so cruel" (51). Little Guálinto, not yet old enough to begin school, is also filled with "[s] trange, terrible questions [that] surged inside him":

Why am I, I? Why are things things and how do I know that they are? Will they be the same when I die like the prayer says, and how will I know they will be the same

when I am dead and can't see them any more? (51-52)

Guálinto's preoccupation with death in these questions is important, for it constitutes a prelude to the murder he will soon witness during playtime.

Guálinto, who "like[s] to play" at the home of Chicho and Poncho Vera, is "playing with Chicho out on the sidewalk" when Meno, the Veras' neighbor, is murdered (55). While Chicho "had vanished with the first shot," Guálinto, "his hands tightly clenched around the pickets of the fence, his face pressed against them," (56) sees the gruesome and cold-blooded murder of the man who, only minutes before, had been chatting with him and Chicho. As a witness to the murder Guálinto is terrified that "the law" will "take him away, pushing him along in front of them and cursing him," and that the policemen will "beat him to make him tell all". While these thoughts run through the little boy's mind, the killers are "in plain sight," standing "down the 
road." (57) Yet the policemen are unconcerned about both the killers' and Guálinto's presence. Finally, Guálinto is able to make his "trembling" (58) body respond, and he races for the safety of his own house.

This brutal disruption of Guálinto's play world emphasizes the real world violence that inhabits the barrio and foregrounds the disregard that "the law" has for the lives of the barrio's inhabitants. Guálinto's witnessing of Meno's murder also dispels the illusion of childhood as a site protected from certain kinds of knowledge. As Guálinto's thoughts reveal, even as a preschooler he has some knowledge of the inequities and cruelties in the world around him, for his fear that "the law" will "curse" and "beat" him even though he is only a small boy who has engaged in no wrongdoing emphasizes the fact that Guálinto knows that these particular lawmen are corrupt. The intrusion of this realworld violence and abuse into Guálinto's playtime also blurs the opposition of Guálinto's "enchanted" home and the "violent" neighborhood that surrounds it, and Guálinto will soon transfer the violence of the real world to the site of his home when he brings a make-believe play world of battle into the banana grove that is "his best friend" and his "playground and playmate" (67).

Although his father's dying wish had been that Guálinto would have no hate in his heart, Guálinto is already experiencing forceful emotions of hate and rage which erupt into fantasies and scenes of imaginary violence. Embarrassed at church when another child makes fun of him for having shortening in his hair (which his mother had decided to use when she found that they were almost out of brilliantine), Guálinto rages inwardly as he walks home:

He hated his mother, he hated everybody, he was alone in the world .... He choked and walked faster, his lower lip trembling. He would go away. They would be sorry, all of them. He would go away and become a big bandit. Or a rinche maybe. And then he would come back and kill people (62).

His thoughts settle on the murder of Meno, and he declares to himself that "he would kill the chief of police who kicked Meno Menchaca after he was dead" (62-63). Guálinto's reeling thoughts continue in vivid and violent detail5: 


\section{Ethnic Studies Review Volume 25}

He'd kill everybody and burn the houses down and his mother would come out crying and asking him not to kill her too. Then he'd sneer coldly and ride away on his big black horse all covered with shiny silver things. Yes, the sissy's sister would notice him then, all dressed up like a charro in black and gold and silver. and Uncle Feliciano .....

No. He couldn't be a rinche, after all. Uncle Feliciano hated the rinches and he'd have to kill him too. Guálinto did not want to do that, so he couldn't be a rinche. But he could fight against the rinches and get killed. That was it. Then they would bring his body home all covered with dirt and blood like Meno Menchaca's. Guálinto shuddered deliciously. (63)

Part imaginative imitation of real-world violence, part reaction to the taunts of others, ${ }^{6}$ and part "self-pity" for himself as a child subjected to adult regulation, this passage shows the conflict of subject positions at war within Guálinto. Moreover, Guálinto's "delicious" hate-filled fantasy of killing and vengeance is in complete opposition to Gumersindo's dying wish that his son should not be consumed with hatred. Requiring Feliciano to keep the circumstances of his death a secret from his son has not guaranteed, after all, that the son will be spared the lessons of life that teach hatred and violence.

Transferring his knowledge of real world hatred and violence to his playworld of the banana grove, six-year-old Guálinto stages a make-believe fight with a banana tree that he has imaginatively transformed into a rinche. In Guálinto's make-believe fight, as in most make-believe play, "the logic of play is the logic of dealing with emotions such as anger, approval, or fear" (Sutton-Smith 158). Thus, "the unreal worlds of play . . . are about how to react emotionally to the experience of living in the world and how to temporarily vivify that experience by transcending its usual limits." (159) In Guálinto's real-world role of child he is considerably limited in his ability to combat the sources of power that confine, ridicule, and constrain him; moreover he is powerless to combat the violence perpetrated on Mexican Americans by Anglos. However through his staging of make-believe combat with a make-believe Texas Ranger, 
Guálinto creatively transforms his position of powerlessness into one of power; he deconstructs "the world in which [he] lived" (166) and in his reconstruction of that world inverts its power.

Consequently in this imaginary battle Guálinto is no longer a taunted child nor the helpless and terrified little boy who witnessed Meno's murder; he is, instead, a fearless defender of his people: Pulling out "from beneath his dotted calico shirt . . . a piece of knotted pine wood whittled into a fair imitation of a dagger," Guálinto shouts, 'Rinche!'" as "he eye[s] the plant in front of him." Challenging the banana-tree rinche, he continues the pretend confrontation:

'Where is Apolonio Gonzalez? . . . Speak, you dog.'

His fingers clasped and unclasped the dagger's haft.

The banana trunk was silent . . Gualinto laughed a harsh laugh. 'A coward,' he said. 'A coward like all your kind.' The object of his hate took the insult meek-

ly, offering no resistance.

Guálinto then escalates his make-believe battle, and, approaching closer to the plant, he accuses the imaginary rinche, "You have killed another Mexican who never hurt you.'" With these words Gualinto lashes out with his imitation dagger, and "a thin trickle of clear fluid ooze[s] out of the plant. Spurred on by this action, Gualinto says with a sneer:

'Why don't you try to kill me, eh? Because you shoot people in the back. Because you kill unarmed men and little children. Go back to your camp and tell old man Keene that Guálinto Gómez doesn't kill men who won't fight.'

Imagining that "the treacherous rinche" is drawing out his gun, Guálinto sinks "his dagger into the wretch's side," and "again and again Guálinto's knife" pierces the make-believe rinche. Guálinto then pushes "the buried dagger deeper and deeper, working it around in the wound to make it more surely fatal" (68).

Guálinto is decidedly the victor in this imaginary battle, and, as Sutton-Smith explains, one of the attractions of play is its "potential promise that one can never quite lose while still at play" (212). However reality intrudes abruptly into Guálinto's imaginary world of conquest disturbing the psychic satisfaction 


\section{Ethnic Studies Review Volume 25}

of this make-believe victory. When Guálinto hears the "sound of his mother's voice . . . calling Maruca," her voice brings him back from his play world into the real world with a jolt. As he surveys the results of his violent encounter with the banana plant, Guálinto finds that "the once-smooth stalk was a pulpy oozing mess, scratched, stabbed and cut, with patches of skinlike bark hanging loose." Guálinto is "frightened" by "the damage" that he has inflicted on the tree; "He had almost killed the plant." He tries frantically "to close up the wounds" on the tree but realizes "he could not hide everything"; even his shirt is "damp from the banana stalk sap," which he knows "no amount of scrubbing could take off" $(68,69) .^{7}$ Back in the real world and fearful of punishment, Guálinto's "everyday self" (Sutton-Smith 159) knows that he has neither the power to kill rinches nor permission to mutilate banana trees.

On a symbolic level Guálinto's violent slaying of the imaginary rinche, whom Guálinto accuses of being a killer of innocent Mexicans, is an enactment of revenge for the slaying of his father, for, even though Guálinto does not know that rinches murdered Gumersindo, he does know that the rinches murder innocent and defenseless people as is evidenced by his play dialogue. As Greta G. Fein states, "Pretend statements can be understood as statements 'of' real-world events based on children's everyday experiencing of these real-world events"; therefore, "pretend scenarios can illuminate children's real-world knowledge" (287). It is also worth noting that in damaging the banana tree Guálinto damages the fruit of his uncle's labor and, in fact, Guálinto will eventually hurt his uncle deeply when he later becomes ashamed both of his family and of the house that Feliciano has worked so hard to provide María and her children.

On still another level this imaginary battle prefigures the real-life knife fight that Guálinto as an adolescent will have with Chucho who provokes Guálinto by making unsavory comments about Guálinto's unmarried and pregnant sister, Maruca. This play battle also points toward the confrontation between Guálinto and the stranger that he fears he has killed near the novel's conclusion. The stranger, however, turns out to be his exiled, seditionist Uncle Lupe whose death is the result of illness and not the blow that Guálinto deals him. Thus Guálinto's play- 
world battle forms an ironic opposition to the real-world battles with both Chucho and Lupe, for in the real world Guálinto fights not rinches but one of his own people and a member of his own family, ${ }^{8}$ and at the close of the novel George G. Gómez spies not on rinches but on the friends of his youth.

Guálinto's disparagement of his own people at the novel's conclusion is foreshadowed by the quick recovery that the child Guálinto makes from his fear of punishment for fatally wounding the banana tree. While resting in the grove after his violent play combat, Guálinto hears a bee buzzing as it meanders through the flowers. Then abruptly all is quiet, until Guálinto hears "a desperate buzz that rose and rose till there was a miniature tornado under the purple leaf" (69). Watching the entangled bee at last extricate "itself from the place where it had been wedged," Guálinto "laugh[s] out loud" as the bee first appears "silent and wobbly," and "[t]hen getting its bearing, [it floats] upward, disappearing into a patch of blue sky that was surrounded by green leaves," once more buzzing "its soft sleepy murmur" (69). This scene functions as a metaphor for Guálinto's own situation, for Guálinto himself is "wedged" between two cultures, and his choice of extrication will involve denying his Mexican heritage by "disappearing" into Americanization in a "desperate" rejection of his own culture and people.

The banana tree grove, the site of both the imaginary battle and the struggling bee, will remain a place of refuge for Guálinto throughout his childhood. At the age of seven when he is whipped unmercifully at school by Miss Cornelia for writing a love note to María Elena Osuna, Guálinto flees to the sanctuary of his banana grove after ramming Miss Cornelia in the gut and making his escape from her clutches. After this beating from Miss Cornelia, Guálinto is transferred to another class, ${ }^{9}$ and upon completing "low first with Miss Josephine, Guálinto passe[s] to high second with Miss Huff, and in so doing enter[s] American school at last."

It is in the schoolroom that he learns to develop "an Angloamerican self, but "on the playground he [is] a Mexican." As he grows older he becomes conscious of these "two clashing forces within him [that] produced a divided personality"; Guálinto becomes aware that he is "many Guálinto Gómezes, 


\section{Ethnic Studies Review Volume 25}

each of them double, like the images reflected on two glass surfaces of a show window" (147). He also becomes aware that even though he may make friends with some of the "little Anglosaxons" inside the classroom, "such friendships do not extend beyond the classroom door," for "on the playground" he is ostracized by these same "little Anglosaxons"; thus, "[t]he Mexicotexan learns to stay away" (149).

According to Sutton-Smith, the playground is "an arena for learning social adaptation" (44), and "social play can be used even as a text to 'interpret' the power relationships within the culture" (74). Guálinto learns that "the power relationships" of the playground carry over into areas outside the schoolyard when, in his teenage years, several of his friends are turned away from a restaurant because they are Mexican. While Guálinto could have chosen to "pass" for Anglo in this situation, he does not. As Héctor Pérez notes, "Guálinto himself is fair-skinned, and his complexion is an issue throughout much of the novel." While he remains with his friends in this instance, that will not be the case when he becomes an adult. The adult George Gomez's "attitude toward darker-skinned Mexicans becomes one element in his rejection of his community" (40). However, during his childhood and adolescence, the oppositions that were fostered in Guálinto in the American school are a constant source of self-acknowledged conflict for him:

Hating the Gringo one moment with an unreasoning hatred, admiring his literature, his music, his material goods the next. Loving the Mexican with a blind fierceness, then almost despising him for his slow progress in the world (150).

As an adult Guálinto will repress this doubleness; however the struggle for synthesis will continue even though the conflict is buried deep within his psyche.

Many of the conflicting emotions that Guálinto experiences revolve around his hate and anger, and he vocalizes his feelings to his close friend, El Colorado, while in the banana tree grove, where, as a young man, Guálinto has returned to prepare, not for an imaginary fight, but for a real one. Fearing retribution from Chucho whom he has stabbed for making snide remarks about Maruca, Guálinto readies himself for battle while in "the banana 
grove, his childhood refuge," where he "practice[s] thrusts with the knife and defensive footwork" (249). Guálinto's conversation with El Colorado during one of these practice sessions exposes Guálinto's hatred, not for Chucho, but for Anglos and for María Elena. Having been spurned by María Elena for the same gringo that had impregnated his sister and having been publicly mocked by María Elena at a local church festival, Guálinto now tells El Colorado that he would like to slit "her pretty white throat," and, as for the "Gringo[s]," he would "like to kill them all, all of them!" $(253,254)$. Later in the novel, when Feliciano finally tells Guálinto that his father was murdered by a rinche, Guálinto cries, "I would like to kill somebody. . . . Why isn't it 1916 right now? . . . Then I could get a rifle and go into the woods and kill and kill and kill'" (264).

However, in spite of the desire to kill that surfaces in Guálinto's boyhood play and in his youthful battle practice, as an adult Guálinto deals with his rage and hatred in another way altogether, for he ends up marrying a gringa ${ }^{10}$ whose father had been a rinche, and he turns his back on his family, his culture, and his friends. Rather than becoming the "leader of his people" (40) as envisioned by his father when he had named Guálinto after George Washington, the adult George G. Gómez, as he has legally renamed himself, is employed as a spy for the American government and is assigned to "watch" the border for "infiltration by German or Japanese agents" (299). As Kaup notes,

After his university education in Austin and his residence with his Anglo wife in Washington, D.C., he returns to the Valley during World War II radically transformed into an American military counterintelligence officer willing to use his Mexican background to inform against his former neighbors, friends, and schoolmates (376).

In his encounter with his Uncle Feliciano after returning home George confirms his uncle's suspicions that he is now a soldier and that he is having his own former friends "watched." George derides his friends as "a bunch of clowns playing at politics" and admits to Feliciano that he can envision "no future" for his people:

Mexicans will always be Mexicans. A few of them, like 


\section{Ethnic Studies Review Volume 25}

some of those would-be politicos, could make something of themselves if they would just do like I did. Get out of this filthy Delta, as far away as they can, and get rid of their Mexican Greaser attitudes (300).

George's adult dreams, however, belie his words, for "the daydreams of his boyhood come back to him in his sleep," daydreams that upon becoming an adult George had thought of as "[p]laying with his little wooden soldiers" (281). Now those daydreams of his childhood-fantasies in which he leads an army of rancheros to victory over the United States, reclaiming all of the land that had once belonged to Mexico-have become the sleepdreams of his adulthood. As Kaup points out, Guálinto/George has grown up in "two opposed environments," which "he . . . cannot remodel to fit the integrated identity his father had dreamed for him," and "his 'Mexicanness' and the heroic role his parents conceived for him as a 'great' man who will help his people ... have receded far into his subconscious" $(375,376)$.

Thus, for Guálinto/George Washington/G. Gómez, his boyhood world of "wooden soldier" dreams lingers as the playing grounds on which his own conflicted identity battles are fought in his adult world of sleep. In the real world, however, George G. Gómez is a flesh-and-blood U.S. soldier who has learned "to play the games of the powerful colonizers" (Sutton-Smith 102). Given the stifling "discourse that portrayed Texas Mexicans as inferior [and] which was circulated in and by ideological state apparatuses, such as the public schools and state authorized historical accounts," (Pérez 30). Paredes can envision no synthesis for Guálinto/George's dilemma of doubleness. According to Pérez, who sees "a sense of hopelessness in the novel-at least as far as radical social and political change for the border community" is concerned-George Washington Gomez' "overall vision, in keeping with naturalist literary projects, seems to be that major, significant social change is unaccomplishable" $(42,45)$. Consequently through both the play battles and the real battles of boyhood and through the lack of synthesis in this coming-ofage narrative, Paredes presents what he sees as the potential for psychic damage and repression that resides in "social reality" (Saldivar, CN 7) on the border for Americans of Mexican descent. 


\section{Notes}

1 While this paper focuses only on Américo Paredes' George Washington Gomez, it is part of a larger project that includes José Antonio Villarreal's Pocho, Rudolfo A. Anaya's Bless Me, Ultima, and Sandra Cisneros's The House on Mango Street.

2 Marco Portales explains, "For fifty years, Paredes' work remained tucked away in the author's dresser, reportedly the object of cold rejections" (82). Because George Washington Gomez carefully chronicles the spiritual, social, and psychological growth prompted by the education received by" its protagonist (83), Portales considers it "Paredes' bildungsroman [that] remains unsurpassed in detailing the educational journeys of several Mexican American students" (83).

3 As Bruce-Novoa states, "History was and is still written mostly by the oppressors to justify themselves, so Chicanos must rewrite history from their own perspective if they want to change the present and the future" (78).

4 This comment by the narrator is to some extent paradoxical, for, as an adolescent, Guálinto is also ashamed of his home. During the scene in which María Elena (who is from a wealthy Mexican family that claims to be Spanish in an attempt to avoid discrimination) drives down Guálinto's street while he is walking home, Guálinto walks past his own house and around the block so that María Elena will not realize that this is where he lives. According to Portales, "Class and racial distinctions have begun to make the young Guálinto feel ashamed of his relatives and neighborhood" (92).

5 Taking my cue from Portales, who notes that he "quote[s] extensively from the work because Paredes' text is not generally known and deserves wider recognition" $(179, n .5), I$ also will quote at length from this important Chicano text.

6 Guálinto is subjected to taunts throughout the novel. Guálinto's mother, not realizing that he has just witnessed a murder, calls him a coward when she believes he has been "frightened" by "the sound of a few shots" (54). On his first day in school, La India, one of the girls in the class, accuses him of "making dirty signs at" her, and, when all of 


\section{Ethnic Studies Review Volume 25}

the girls chime in with "indignation" at this fabrication, Guálinto is reduced to tears (122). In addition to being called a coward by his mother and being taunted by La India, Guálinto is also verbally as well as physically abused by Miss Cornelia throughout his stay in her class. 7 Arguably, this could be a foreshadowing of the adult George's attempt to wash his hands of his own people and his own Mexicanness. However as an adult George finds that he cannot totally rid himself of his loyalties to his Mexican heritage, for his boyhood fantasies of victory for Mexico surface in his adult dream world.

8 Héctor Pérez likewise notes, "It is clear that Chucho is a convenient substitute for the rinche figure" (44). Regarding Guálinto's encounter with Lupe, Pérez asserts, "When Guálinto strikes Lupe, he not only fatally injures the prison escapee but strikes a deadly blow against his family and more symbolically against the earlier generation of Chicanos who resisted Anglo encroachment and fought as seditionists." According to Pérez, "George Washington Gómez is an Oedipal neoChicano who kills his seditionist father" (41).

9 Portales notes that the beating that Guálinto receives from "Miss Cornelia, his Mexican American low first grade teacher . . . leads his uncle, Feliciano Garcia, to visit the principal with two lawyers by his side, a state of affairs that Mexican Americans have often had to resort to in Texas in order to improve the nature and the quality of education" (85).

10 The women who have taunted, beaten, or abused Guálinto have all been of Mexican descent. His marriage to a gringa signifies the unresolved nature of both the racial and the gender conflicts that have plagued him since childhood. Pérez, noting the racial dynamics in the novel, states, "The community is not entirely innocent of racial biases, for in it are people like the Osunas who deny their Mexican Indian heritage and pass as Spaniards, European and white." Furthermore, according to Pérez, the "women in the novel internalize a gendered code of behavior as a microcosm of larger oppressive systems," and "Guálinto's mother and his first schoolteacher-both figures in important relationships for a person's psychological social development-are especially pertinent cases." María Elena Osuna's rejection of Guálinto can also be seen "as a microcosm of larger oppressive systems," for, as previously noted, she and her family "pass as Spaniards, European and white" $(39,40)$, and she verbally and publicly denigrates Guálinto's Mexicanness. 


\section{Works Cited}

Bruce-Novoa, Juan. 1990. Retrospace: Collected Essays on Chicano Literature, Theory, and History. Houston: Arte Publico.

Fein, Greta G. 1987. "Pretend Play." Curiosigination and Play: On the Developmental Motivational Processes. Ed. Dietmar Gorlitz and Joachim F. Wohlwill. Hillsdale, NJ: LEA. 282-304.

Kaup, Monika. 1997. "The Architecture of Ethnicity in Chicano Literature." American Literature.

Lyon, Ted. 1979. "'Loss of Innocence' In Chicano Prose." The Identification and Analysis of Chicano Literature. Ed. Francisco Jimenez. New York: Bilingual Press. 254-62.

Paredes, Américo. 1990. George Washington Gomez: A Mexicotexan Novel. Huston: Arte Publico.

Pérez, Héctor. 1998. "Voicing Resistance on the Border: A Reading of Américo Paredes' George Washington Comez." MELUS 3:27-48.

Portales, Marco. 2000. Crowding Out Latinos: Mexican Americans in the Public Consciousness. Philadelphia: Temple U P.

Saldívar, Ramón. 1990. Chicano Narrative: The Dialectics of Difference. Madison: $U$ of WI P.

- - -. 1993. "The Borderlands of Culture: Américo Paredes' Ceorge Washington Gómez and Chicano Literature at the End of the Twentieth Century." American Literary History. 5:272-93.

Sánchez, Rosaura. 1997. "Discourses of Gender, Ethnicity, and Class in Chicano Literature." Feminisms: An Anthology of Literary Theory and Criticism. Ed. Robyn R. Warhol and Diane Price Herndl. New Brunswick: Rutgers U P. 1009-22.

Sutton-Smith, Brian. 1997. The Ambiguity of Play. Cambridge: Harvard U P. 512 